\title{
PENGEMBANGAN KURIKULUM DIKLAT PUBLIKASI ILMIAH SEBAGAI BENTUK FASILITASI PENINGKATAN KOMPETENSI GURU DALAM MENULIS BEST PRACTICE
}

\author{
Rr Sri Sukarni Katamwatiningsih \\ Balai Diklat Keagamaan Semarang \\ sukarni_bdk@yahoo.com
}

http://doi.org/DOI 10.37730/edutrained.v4i1.58

Diterima: 16 Maret 2020 | Disetujui: 30 Juni 2020 | Dipublikasikan: 6 Juli 2020

\begin{abstract}
Abstrak
Penelitian ini bertujuan untuk mengembangkan kurikulum Diklat Publikasi Ilmiah, sebagai bentuk tindak lanjut implementasi Publikasi Ilmiah, khususnya best practice. Penelitian ini dilakukan dengan metode Penelitian R \& D. Kurikulum yang dikembangkan adalah Kurikulum Diklat Publikasi Ilmiah yang terdapat dalam SK Kepala Badan Litbang dan Diklat Nomor 62 Tahun 2017 tentang Kurikulum Pendidikan dan Pelatihan Tenaga Teknis Pendidikan dan Keagamaan. Obyek penelitian adalah peserta diklat publikasi ilmiah. Terdapat 3 (tiga) langkah pokok, yaitu (1) studi pendahuluan; (2) pengembangan model; dan (3) validasi model. Dalam studi pendahuluan, peserta diklat dalam menuliskan publikasi ilmiah terfokus pada penulisan tinjauan ilmiah (best practice). Pengembangan model difokuskan pada mata diklat Tinjauan Ilmiah untuk dilaksanakan dalam pembimbingan. Validasi model diperoleh validasi materi dan publikasi dari ahli sesuai keahliannya. Dalam uji coba ini peserta tidak diwajibkan untuk menulis produk tertentu tapi dapat memilih sesuai dengan kebutuhan peserta diklat. Dari 10 peserta diklat 5 orang menuliskan best practice, maka dalam kajian ini terfokus untuk membahas best practice. Hasil uji coba tersebut diimplementasikan pada 105 peserta. Dalam penelitian ini yang dikembangkan mata diklat best practice, dalam penentuan alokasi waktu setiap mata diklat 15 jam pelajaran. Setiap mata diklat dapat dijabarkan sesuai dengan sistematika penulisan karya ilmiah. Simpulan penelitian ini adalah kurikulum publikasi ilmiah mata diklat tinjauan ilmiah dapat dikembangkan dan dapat dijadikan pedoman pembimbingan.
\end{abstract}

Kata Kunci: Publikasi Ilmiah, Fasilitasi, Menulis Best Practice

\begin{abstract}
This study aims to develop a curriculum for Scientific Publication Training, as a form of follow-up for the implementation of Scientific Publications, especially best practice. This research is conducted with the R\&D Research method. The curriculum developed is the Scientific Publication Education and Training Curriculum contained in the Decree of the Head of the Research and Development Agency No. 62 of 2017 concerning Education and Training Curriculum for Technical Education and Religious Personnel. The object of the research is the participants of the scientific publication training. There are 3 (three) main steps, namely (1) a preliminary study; (2) model development; and (3) model validation. In the preliminary study, the training participants in writing scientific publications focused on writing scientific reviews (best practice). The development of the model focused on the subject of Scientific review training to be carried out in mentoring. Model validation obtained material validation and publication from experts according to their expertise. In this trial participants was not required to write certain products but can choose according to the training participants' needs. From 10 training participants 5 people wrote best practices, so in this study focused on discussing best practice. The results of the trial were implemented in 105 participants. In this study, the best practice training course was developed, in determining the time allocation for each course of 15 hours of training. Each course can be elaborated according to the systematic writing of scientific papers. The conclusion of this research is the curriculum of scientific publications in the field of scientific review training can be developed and can be used as guidance for guidance.
\end{abstract}

Keywords: Scientific Publications, Facilitation, Writing Best Practices 


\section{PENDAHULUAN}

Peraturan Menteri Agama (PMA) Nomor 75 Tahun 2015 tentang Penyelengaraan Pendidikan dan Pelatihan Pegawai pada Kementerian Agama pasal 1 ayat 1 menyatakan Pendidikan dan Pelatihan yang selanjutnya disebut Diklat adalah penyelenggaraan pembelajaran dan pelatihan dalam rangka mengembangkan kompetensi pegawai sesuai persyaratan jabatan masing-masing pada Kementerian Agama yang dilaksanakan paling sedikit 40 jam pelajaran dengan durasi jam pelajaran 45 menit.

Sebagai mana tercantum pada pasal 2 ayat a, dan $\mathrm{d}$ :

Penyelenggaraan diklat bertujuan meningkatkan pengetahuan, keahlian, keterampilan dan sikap pegawai untuk melaksanakan tugas jabatan secara profesional yang dilandasi kepribadian dan kode etik pegawai sesuai dengan kebutuhan Kementerian Agama, menciptakan pegawai yang berkualitas, profesionalitas, integritas dan bertanggungjawab.

Balai Diklat Keagamaan Semarang merupakan salah satu pelaksana Teknis Diklat Kementerian Agama. Balai Diklat Keagamaan Semarang melaksanakan Diklat Substantif dalam rangka pencapaian kompetensi yang terkait dengan pekerjaan yang bersangkutan, sehingga mampu melaksanakan tugas dan tanggungjawabnya secara profesional seperti yang tercantum pada PMA Nomor 75 tahun 2015 pasal 8 ayat 4. Berdasarkan PMA tersebut diterbitkan Surat Keputusan Kepala Badan Litbang dan Diklat Kementerian Agama Republik Indonesia No 62 tahun 2017 tentang Kurikulum Pendidikan dan Pelatihan Tenaga Teknis Pendidikan dan Keagamaan Tahun 2017 beserta lampirannya. Di dalam lampiran tersebut diatur nama-nama Kurikulum dan Diklat Tahun 2018, salah satunya Diklat Teknis Substantif Publikasi Ilmiah. Diklat tersebut dilaksanakan dalam waktu 60 Jam pelajaran dalam waktu 6 hari. Struktur Kurikulum yang terdapat dalam Diklat Teknis
Substantif Publikasi Ilmiah terdiri dari kelompok dasar 9 Jam Pelajaran (JP), kelompok inti 43 JP dan kelompok penunjang $8 \mathrm{JP}$. Khususnya pada kelompok inti terdapat mata diklat Konsep Dasar Publikasi Ilmiah, Publikasi Ilmiah bentuk Hasil Penelitian, Publikasi Ilmiah bentuk Makalah Tinjauan Ilmiah, Publikasi Ilmiah bentuk buku, Publikasi Ilmiah bentuk Tulisan Ilmiah Populer.

Di dalam Kurikulum kediklatan pada kelompok penunjang terdapat mata diklat Rencana Tindak Lanjut (RTL), di mana peserta diklat setelah kediklatan diharapkan dapat melakukan tindak lanjut dari apa yang telah didapatkan dari materi kediklatan kelompok inti. Pelaksanaan RTL ini belum memiliki standar kurikulum tersendiri=

Salah satu mata diklat pada Kurikulum Diklat Publikasi Ilmiah adalah Publikasi Ilmiah bentuk Makalah Tinjauan Ilmiah berupa best practice. Best practice adalah sebuah karya tulis yang menceritakan pengalaman terbaik dalam menyelesaikan sebuah permasalahan yang dihadapi oleh pendidik dan tenaga kependidikan sehingga mampu memperbaiki mutu layanan pendidikan dan pembelajaran. Kompetensi Dasar aspek pengetahuan pada mata diklat ini menyatakan peserta diklat menganalisis perbedaan makalah berupa tinjauan ilmiah dan pengalaman terbaik (best practice), sedangkan kompetensi dasar aspek ketrampilan adalah mempraktikan penulisan makalah tinjauan ilmiah atau pengalaman terbaik (Kurikulum Pusdiklat, 2018).

Best practice merupakan produk mata diklat tinjauan ilmiah, sehingga dijadikan sebagai kajian RTL. RTL dibuat peserta setelah mengikuti seluruh mata diklat. Peserta diwajibkan untuk mengiplementasikan penyusunan publikasi ilmiah di instansi masing-masing dengan bimbingan Widyaiswara yang telah ditugaskan oleh pimpinan. Oleh karena itu dalam melaksanakan RTL balai diklat menyelenggarakan fasilitasi peningkatan kompetensi guru dalam melaksanakan tinjauan ilmiah berupa best practice. Hasil dari konsultasi peserta diklat merevisi hasil 
konsultasi dan mengirimkan kembali ke Balai Diklat Keagamaan Semarang.

Berikut ini diuraikan beberapa masalah berkaitan dengan kompetensi guru dalam menulis karya tulis ilmiah, khususnya menulis best practice. Hasil pengamatan dan refleksi pengalaman penulis membimbing guru melaksanakan Publikasi Ilmiah dalam kurun waktu 4 tahun terakhir di beberapa kabupaten/kota di Provinsi Jawa Tengah, 1) $75 \%$ guru yang mengikuti workshop, bimbingan teknis, atau pelatihan Publikasi Ilmiah belum pernah menuliskan pengalaman terbaik yang dialami, 2) $75 \%$ guru belum pernah mengikuti fasilitasi pelatihan Publikasi Ilmiah, dan 3), 67,7\% guru dengan golongan III/b sampai IV/a yang terkendala kenaikan pangkat /golongannya karena mereka belum dapat memenuhi angka kredit dari subunsur publikasi ilmiah dan/atau karya inovatif.

Berdasarkan uraian di atas perlu dikembangkan fasilitasi atau pembimbingan Publikasi Ilmiah terutama dalam penulisan best practise untuk membantu guru dalam melaksanakan melaksanakan Pengembangan Keprofesioan Berkelanjutan (PKB). Fasilitasi yang dimaksud menurut Peraturan Kepala Lembaga Administrasi Negara Nomor 13 tahun 2011, pasal 1 dan 2 , sebagai fasilitasi teknis. Secara lebih khusus, fasilitasi teknis untuk guru yang dimaksud menurut pasal 6, termasuk jenis fasilitasi teknis substantif.

Hal yang sangat penting terkait penyelenggaraan fasilitasi atau pembimbingan best practice bertujuan untuk mengembangkan kompetensi guru dalam menuliskan publikasi ilmiah. Dengan pola fasilitasi ini merupakan tindak lanjut untuk membimbing guru dalam mengembangkan kompetensinya. Fasilitasi merupakan tindak lanjut untuk-memastikan kompetensi-kompetensi apa saja yang dibutuhkan oleh madrasah, bagaimana mengukur pencapaian kompetensi yang dilatih, serta indikator-indikator apa saja yang diterapkan untuk mengetahui apakah guru telah menguasai kompetensi yang diberikan. Oleh karena itu, penelitian ini dimaksudkan untuk memberikan kajian dan pemikiran tentang perlunya pengembangan kurikulum diklat publikasi ilmiah sebagai bentuk fasilitasi peningkatan kompetensi guru dalam menulis best practice.

Tujuan penelitian ini adalah mengembangkan kurikulum Diklat Publikasi Ilmiah BDK Semarang sebagai bentuk fasilitasi peningkatan kompetensi guru dalam menulis best practice.

\section{KAJIAN PUSTAKA}

\section{Kurikulum}

Menurut UU Nomor 20 tahun 2003, kurikulum merupakan seperangkat rencana dan pengaturan mengenai tujuan, isi, dan bahan pelajaran serta cara yang digunakan sebagai pedoman penyelenggaraan kegiatan pembelajaran untuk mencapai tujuan pendidikan tertentu. Kurikulum sebagai rancangan pendidikan mempunyai kedudukan yang sangat strategis dalam seluruh aspek kegiatan pendidikan. Kurikulum adalah serangkaian rencana yang disusun demi melancarkan proses belajar-mengajar (Nasution, 2009). Kurikulum merupakan kumpulan niat dan harapan yang tertuang dalam bentuk program pendidikan yang mana dilaksanakan oleh guru di sekolah (Sudjana, 2005). Jadi, dapat disimpulkan bahwa kurikulum merupakan alat atau saran yang dirumuskan demi tercapainya tujuan pendidikan melalui proses pengajaran.

Mengingat pentingnya peranan kurikulum di dalam pendidikan dan dalam perkembangan kehidupan manusia, maka dalam penyusunan kurikulum tidak bisa dilakukan tanpa menggunakan landasan yang kokoh dan kuat. Kurikulum merupakan inti dari bidang pendidikan dan memiliki pengaruh terhadap seluruh kegiatan pendidikan, maka penyusunan kurikulum tidak dapat dilakukan secara sembarangan. Penyusunan kurikulum membutuhkan landasan-landasan yang kuat, yang didasarkan pada hasil-hasil pemikiran dan penelitian yang mendalam. Penyusunan kurikulum yang tidak didasarkan pada landasan yang kuat dapat berakibat fatal terhadap pendidikan itu sendiri. 


\section{Pengembangan Kurikulum}

Sanjaya (2008:43), ada empat fungsi filsafat dalam proses pengembangan kurikulum. Pertama, filsafat dapat menentukan arah dan tujuan pendidikan. Kedua, filsafat dapat menentukan isi atau materi pelajaran yang harus diberikan sesuai dengan tujuan yang ingin dicapai. Ketiga, filsafat dapat menentukan strategi atau cara pencapaian tujuan. Keempat, melalui filsafat dapat ditentukan bagaimana menentukan tolak ukur keberhasilan proses pendidikan.

Pada dasarnya ada dua jenis psikologi yang memiliki kaitan yang sangat erat dan harus dijadikan sumber pemikiran dalam mengembangkan kurikulum, yaitu: psikologi perkembangan dan psikologi belajar. Psikologi perkembangan adalah ilmu atau studi yang mengkaji perkembangan manusia, beserta kecenderungan perilaku yang ditunjukannya. Adapun psikologi belajar, adalah suatu pendekatan atau studi yang mengkaji bagaimana manusia umumnya melakukan proses belajar.

Pengembangan kurikulum adalah proses perencanaan dan penyusunan kurikulum oleh pengembang kurikulum (curriculum developer) dan kegiatan yang dilakukan agar kurikulum yang dihasilkan dapat menjadi bahan ajar dan acuan yang digunakan untuk mencapai tujuan pendidikan (Suparlan, 2011)

Pada hakikatnya pengembangan kurikulum itu merupakan usaha untuk mencari bagaimana rencana dan pengaturan mengenai tujuan, isi, dan bahan pelajaran serta cara yang digunakan sebagai pedoman penyelenggaraan kegiatan pembelajaran yang sesuai dengan perkembangan dan kebutuhan untuk mencapai tujuan tertentu dalam suatu lembaga. Pengembangan kurikulum diarahkan pada pencapaian nilai-nilai umum, konsep-konsep, masalah dan keterampilan yang akan menjadi isi kurikulum yang disusun dengan fokus pada ketrampilan menulis. Selain berpedoman pada landasan-landasan yang ada, pengembangan kurikulum juga berpijak pada prinsip-prinsip pengembangan kurikulum.

\section{Kurikulum Diklat Publikasi Ilmiah}

Kurikulum yang terdapat dalam SK Kepala Badan Litbang dan Diklat No 62 Tahun 2017 tentang Kurikulum Pendidikan dan Pelatihan Tenaga Teknis Pendidikan dan Keagamaan sebagai berikut .

Tabel 1. Kurikulum Diklat Publikasi Ilmiah

\begin{tabular}{|c|c|c|c|}
\hline \multirow{2}{*}{ NO } & \multirow{2}{*}{ MATA DIKLAT } & \multicolumn{2}{|c|}{ JAM DIKLAT } \\
\hline & & Teori & Praktik \\
\hline A & KELOMPOK DASAR & & \\
\hline 1 & $\begin{array}{l}\text { Pembangunan Bidang } \\
\text { Agama }\end{array}$ & 3 & \\
\hline 2 & $\begin{array}{l}\text { Pengembangan Sumber } \\
\text { Daya Manusia } \\
\text { Kementerian Agama }\end{array}$ & 3 & \\
\hline \multirow[t]{2}{*}{3} & $\begin{array}{l}\text { Peningkatan Kualitas Diklat } \\
\text { Tenaga Teknis Pendidikan } \\
\text { dan Keagamaan }\end{array}$ & 3 & \\
\hline & Jumlah & 9 & \\
\hline B & KELOMPOK INTI & & \\
\hline 1 & $\begin{array}{l}\text { Konsep Dasar Publikasi } \\
\text { Ilmiah }\end{array}$ & 3 & \\
\hline 2 & $\begin{array}{l}\text { Publikasi Ilmiah Bentuk } \\
\text { Laporan Hasil Penelitian }\end{array}$ & 3 & 7 \\
\hline 3 & $\begin{array}{l}\text { Publikasi Ilmiah Bentuk } \\
\text { Makalah Tinjauan Ilmiah }\end{array}$ & 3 & 7 \\
\hline 4 & $\begin{array}{l}\text { Publikasi Ilmiah Bentuk } \\
\text { Buku }\end{array}$ & 3 & 7 \\
\hline \multirow[t]{2}{*}{5} & $\begin{array}{l}\text { Publikasi Ilmiah Bentuk } \\
\text { Tulisan Ilmiah Populer }\end{array}$ & 3 & 7 \\
\hline & Jumlah & 15 & 28 \\
\hline $\mathbf{C}$ & KELOMPOK PENUNJANG & & \\
\hline 1 & Overview & & 1 \\
\hline 2 & $\begin{array}{l}\text { Building Learning } \\
\text { Commitment }\end{array}$ & 2 & 2 \\
\hline 3 & Evaluasi Program & & 1 \\
\hline \multirow[t]{4}{*}{4} & Rencana Tindak Lanjut & & 2 \\
\hline & Jumlah & 2 & 6 \\
\hline & Jumlah Teori dan Praktik & 26 & 34 \\
\hline & TOTAL & \multicolumn{2}{|c|}{60} \\
\hline
\end{tabular}

\section{Publikasi Ilmiah Bentuk Best Practice}

Kata best practice digunakan untuk mendeskripsikan/menguraikan "pengalaman terbaik" dari keberhasilan seseorang atau kelompok dalam melaksanakan tugas, termasuk dalam mengatasi berbagai masalah dalam lingkungan tertentu. Untuk guru terutama adalah pembelajaran di sekolah. Best practice memiliki ciri-ciri sebagai berikut.

a. Best practice mampu mengembangkan cara baru dan inovatif dalam pengembangan serta memecahkan masalah dalam pendidikan khususnya pembelajaran; 
b. Best Practice membawa sebuah perubahan/ perbedaan sehingga sering dikatakan hasilnya luar biasa (outstanding result);

c. Best practice mampu mengatasi persoalan tertentu secara berkelanjutan (keberhasilan lestari) atau dampak dan manfaatnya berkelanjutan/ tidak sesaat;

d. Best practice mampu menjadi model dan memberi inspirasi dalam membuat kebijakan (pejabat) serta inspiratif guru lainnya, termasuk murid;

e. Cara dan metoda yang dilakukan dan atau yang digunakan bersifat ekonomis dan efisien (Suryani, 2017).

Best practice guru, merupakan sebuah publikasi ilmiah yang memaparkan hal ihwal pengalaman terbaik yang telah dilakukan selama melaksanakan tugas tugasnya dalam pembelajaran termasuk mengatasi masalah, dengan ciri-ciri hasil luar biasa (outstanding), inovatif, dampaknya berkelanjutan (sustainable), inspiratif dan efisien/ekonomis, diwarnai dengan moralitas.

\section{METODE PENELITIAN}

Penelitian tentang model desain pengembangan kurikulum ini dilakukan dengan metode Penelitian dan Pengembangan / Research and Development) $(R \& D)$.; Prinsip dari metoda ini, adalah mengembangkan suatu produk pendidikan, mengujicobakan produk di lapangan, dan menyempurnakan produk berdasarkan data dari lapangan (Sugiyono: 2009). Metode $R \& D$ dapat untuk mengembangkan dan memvalidasi produk pendidikan yang merupakan salah satu strategi dalam meningkatkan mutu pendidikan. Tahap penelitian sesuai teori Borg dan Gall dalam Sukmadinata (2007) sebagai berikut.

a. Penelitian dan pengumpulan data (research and information collecting), yang meliputi pengukuran kebutuhan, studi literatur, penelitian dalam skala kecil, dan pertimbangan-pertimbangan dari segi nilai.

b. Perencanaan (planning), yaitu menyusun rencana penelitian yang meliputi kemampuan-kemampuan yang diperlukan dalam pelaksanaan penelitian, rumusan tujuan yang hendak dicapai dengan penelitian tersebut, desain atau langkah-langkah penelitian, kemungkinan pengujian dalam lingkup terbatas.

c. Pengembangan draf produk (develop preliminary form of product), yaitu pengembangan bahan pembelajaran, proses pembelajaran dan instrumen evaluasi.

d. Uji coba lapangan awal (preliminary field testing). Selama uji coba berlangsung, peneliti mengadakan pengamatan, wawancara dan pengedaran angket.

e. Merevisi hasil uji coba (main product revision), yaitu memperbaiki atau menyempurnakan hasil uji coba.

f. Uji coba lapangan (main field testing). Selama uji coba lapangan, peneliti mengumpulkan data kuantitatif penampilan guru sebelum dan sesudah menggunakan model yang diuji cobakan, kemudian hasil-hasil pengumpulan data tersebut dievaluasi dan kalau mungkin dibandingkan dengan kelompok pembanding.

g. Penyempurnaan produk hasil uji lapangan (operasional product revision), yaitu menyempurnakan produk hasil uji lapangan

h. Uji pelaksanaan lapangan (operasional field testing). Pengujian dilakukan melalui angket, wawancara, dan observasi kemudian hasilnya dianalisis.

i. Penyempurnaan produk akhir (final product revision). Penyempurnaan didasarkan pada masukan dari uji pelaksanaan lapangan.

j. Diseminasi dan Implementasi (dissemination and implementation), yaitu melaporkan hasilnya dalam pertemuan profesional dalam jurnal, bekerjasama dengan penerbit untuk penerbitan dan memonitor penyebaran untuk pengontrolan kualitas.

Pada langkah penyempurnaan dan desiminasi, belum dilakukan karena keterbatasan waktu dan obyek pelaksanaan, sehingga langkah-langkah yang dapat penelitian dilakukan sebagai berikut. 

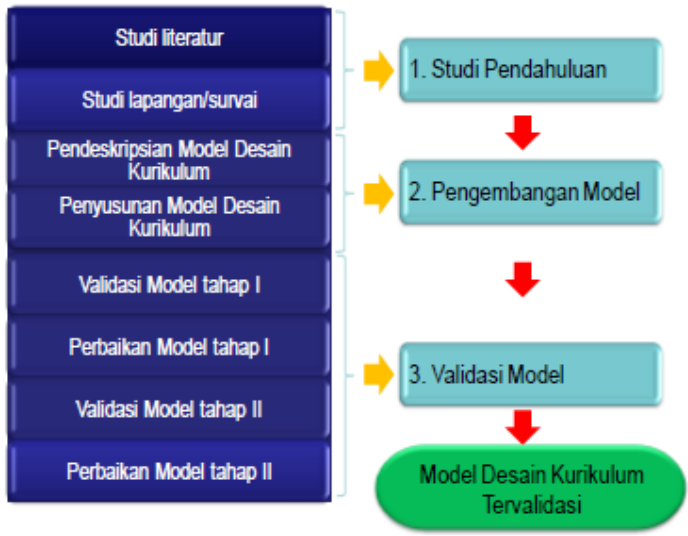

Gambar 1. Tahap penelitian sesuai Teori Borg dan Gall

Pengolahan data dilakukan dengan langkah-langkah, yaitu: pertama, analisis dan pengolahan data yang berkaitan dengan studi evaluatif terhadap kurikulum diklat yang diterapkan di Balai Diklat Keagamaan Semarang. Kedua, analisis dan pengolahan data yang berkaitan dengan kegiatan uji coba tahap I (validasi) terhadap model desain kurikulum pelatihan berdasarkan kompetensi yang dihasilkan, Ketiga, analisis dan pengolahan data yang berkaitan dengan kegiatan uji coba tahap II (simulasi di lapangan). Ketiga jenis data tersebut, diolah dengan cara mereduksi data, mengelompokkan data dan memaknai atau menginterpretasikan data yang berhasil dijaring. Analisis data dilakukan, secara deskriptif. Kesimpulan berupa validitas model desain kurikulum pelatihan berdasarkan kompetensi didasarkan pada hasil penilaian para ahli mengenai kesesuaian model desain kurikulum pelatihan yang dihasilkan dalam penelitian ini. Efektivitas model desain kurikulum pelatihan terhadap pencapai tujuan pelatihan dan kesiapan model desain kurikulum pelatihan tersebut untuk dioperasionalkan di lapangan ditentukan atas dasar hasil simulasi yang dilakukan Balai Diklat Keagamaan Semarang. Kegiatan penelitian dilakukan dengan langkahlangkah: 1) studi pendahuluan; 2) pengembangan model; dan 3) validasi model

Penelitian dilaksanakan di Balai Diklat Keagamaan Semarang, -Kantor Kementerian Agama Kabupaten/Kota seluruh Jawa
Tengah, dan di madrasah sesuai tempat tugas peserta dalam kurun waktu sesuai jadual pelatihan yang telah di programkan pada tahun 2020. Pelatihan Publikasi Ilmiah dilaksanakan dalam bentuk Diklat reguler, Diklat Di Wilayah Kerja (DDWK) dan Diklat Kerja Sama (DKS). Obyek penelitian adalah para guru madrasah diutamakan yang terkendala dalam kenaikan pangkat dikarenakan belum terpenuhi unsur Publikasi Ilmiah dan/atau Karya Inovasi.

\section{HASIL PENELITIAN DAN PEMBAHASAN}

\section{Hasil Penelitian}

Diklat Publikasi Ilmiah dilaksanakan dalam bentuk diklat reguler, Diklat Di Wilayah Kerja dan Diklat Kerjasama. Uji Coba pengembangan kurikulum Publikasi Ilmiah dilaksanakan pada diklat guru di wilayah kerja Kantor Kementerian Agama Kabupaten Wonogiri dan Kabupaten Cilacap.

a. Studi Pendahuluan

Peneliti mengkaji Kurikulum Diklat Publikasi Ilmiah. Peneliti menetapkan RTL best practice sebagai kegiatan pengembangan kurikulum diklat. Penulis mengambil sample 10 peserta diklat sebagai uji coba yang telah ditugaskan untuk menyelesaikan Rencana Tindak Lanjut (RTL). Dalam implementasi RTL peserta diklat membuat karya ilmiah dapat berbentuk: hasil penelitian, tinjauan ilmiah (best practice), buku dan artikel populer. Dari uji coba hasil sebagai berikut.

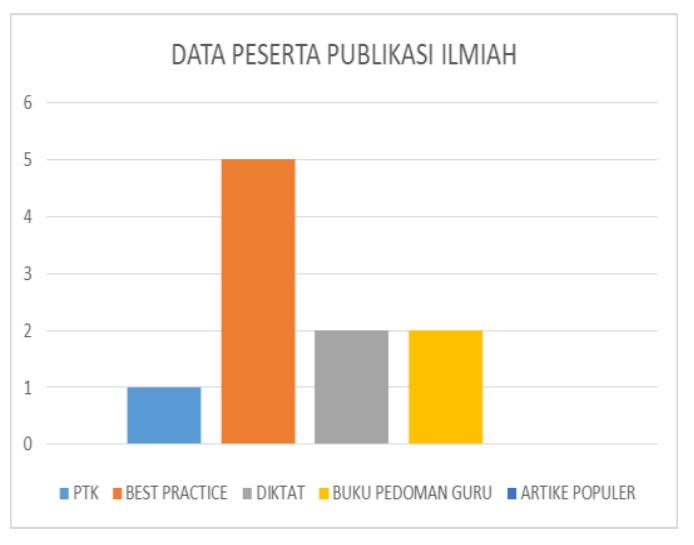

Grafik 1. Uji coba hasil RTL 
Dari data tersebut dapat dilihat dari 10 peserta diklat; 1 orang menuliskan proposal PTK, 5 orang menuliskan best practice, 2 orang menulis diktat dan 2 orang menulis buku pedoman guru, dan tak seorangpun peserta yang menulis artikel populer. Dalam uji coba ini peserta tidak diwajibkan untuk menulis produk tertentu tapi dapat memilih sesuai dengan kebutuhan peserta diklat. Dari 10 peserta diklat 5 orang $50 \%$ menuliskan best practice, maka dalam kajian ini terfokus untuk membahas best practice.

b. Pengembangan Model

Pembimbingan dilaksanakan dalam waktu 1 bulan. dalam menfasilitasi best practice ada beberapa indikator yang dapat menjadi acuan sebagai kajian konsultasi peserta diklat, sebagai berikut.

Tabel 2. Komponen Kurikulum Tinjauan Ilmiah

\begin{tabular}{|c|c|c|}
\hline NO & KOMPONEN & KET \\
\hline \multicolumn{3}{|c|}{ ISI MAKALAH } \\
\hline & judul & $2 \mathrm{JP}$ \\
\hline \multirow[t]{5}{*}{ A. } & Pendahuluan & $3 \mathrm{JP}$ \\
\hline & 1. Latar Belakang & \\
\hline & 2. perumusan masalah & \\
\hline & 3. Tujuan & \\
\hline & 4. Manfaat & \\
\hline \multirow[t]{2}{*}{ B. } & Kajian/tinjauan pustaka & $3 \mathrm{JP}$ \\
\hline & $\begin{array}{l}\text { Teori yang mendasari } \\
\text { permasalahan yang diangkat }\end{array}$ & \\
\hline \multirow[t]{4}{*}{ C. } & Pembahasan masalah & $3 \mathrm{JP}$ \\
\hline & Kondisi awal & \\
\hline & $\begin{array}{l}\text { Proses penyelesaian } \\
\text { masalah }\end{array}$ & \\
\hline & Kendala yang dihadapi & \\
\hline \multirow[t]{2}{*}{ D. } & Kesimpulan & $2 \mathrm{JP}$ \\
\hline & Intisari dari best practice & \\
\hline \multirow[t]{2}{*}{ E. } & Daftar pustaka & $1 \mathrm{JP}$ \\
\hline & $\begin{array}{l}\text { Kesesuaian sumber yang } \\
\text { dirujuk }\end{array}$ & \\
\hline \multirow[t]{5}{*}{$\mathrm{F}$. } & Lampiran-Lampiran & $1 \mathrm{JP}$ \\
\hline & $\begin{array}{l}\text { a. data yang digunakan } \\
\text { dalam melakukan }\end{array}$ & \\
\hline & tinjauan ilmiah & \\
\hline & $\begin{array}{l}\text { b. dokumen menunjang } \\
\text { tinjauan ilmiah }\end{array}$ & \\
\hline & Total Jam pembelajaran & $15 \mathrm{JP}$ \\
\hline
\end{tabular}

c. Validasi Model

Pada tahap ini dilakukan validasi dan perbaikan masing-masing sebanyak 2 (dua) tahap. Revisi pengembangan Kurikulum Publikasi Ilmiah yang telah disusun divalidasi melalui 1) ahli materi yang berkompeten di bidang karya ilmiah; dan 2) ahli publikasi ilmiah yang berpengalaman penulisan publikasi ilmiah.

Sebelum melakukan ujicoba, komponen mata diklat yang dikembangkan divalidasi terlebih dahulu oleh ahli materi (spesialisasi). Validasi materi dilaksanakan oleh widyaiswara yang mempunyai latar belakang spesialisasi Karya Tulis Ilmiah sesuai dengan materi yang dikembangkan. Validasi oleh ahli materi bertujuan untuk mendapatkan informasi, kritik, dan saran agar komponen mata diklat yang dikembangkan menjadi produk yang berkualitas secara aspek materi, penulisan dan kebahasaan, hasil validasi dari tiga aspek tahap pertama $72 \%$ tahap dan kedua $83,3 \%$. Hasil validasi aspek publikasi tahap pertama $67 \%$ dan tahap kedua $76 \%$

\section{Pembahasan}

Implementasi

pengembangan kurikulum Publikasi Ilmiah dilaksanakan pada diklat reguler dan diklat kerjasama di wilayah kerja Kantor Kementerian Agama Kabupaten Pati dan Kendal. Penulis mengambil sampel 105 peserta diklat yang telah ditugaskan untuk menyelesaikan Rencana Tindak Lanjut (RTL).

Dalam implementasi RTL peserta diklat membuat karya ilmiah dapat berbentuk hasil penelitian, tinjauan ilmiah (best practice), buku dan artikel populer. Hasil implementasi dari uji coba dikembangkan pada peserta yang lebih banyak. Hasil sebagai berikut. 
Tabel 3. Data Peserta Publikasi Ilmiah

\begin{tabular}{ccccccc}
\hline NO & NAMA & PTK & BP & DIKTAT & BP & AP \\
\hline 1 & X & 1 & 15 & 5 & 7 & 7 \\
2 & Y & 2 & 14 & 7 & 8 & 4 \\
3 & $\mathrm{Z}$ & 1 & 14 & 7 & 5 & 8 \\
\hline & TOTAL & 4 & 43 & 19 & 20 & 19 \\
\hline
\end{tabular}
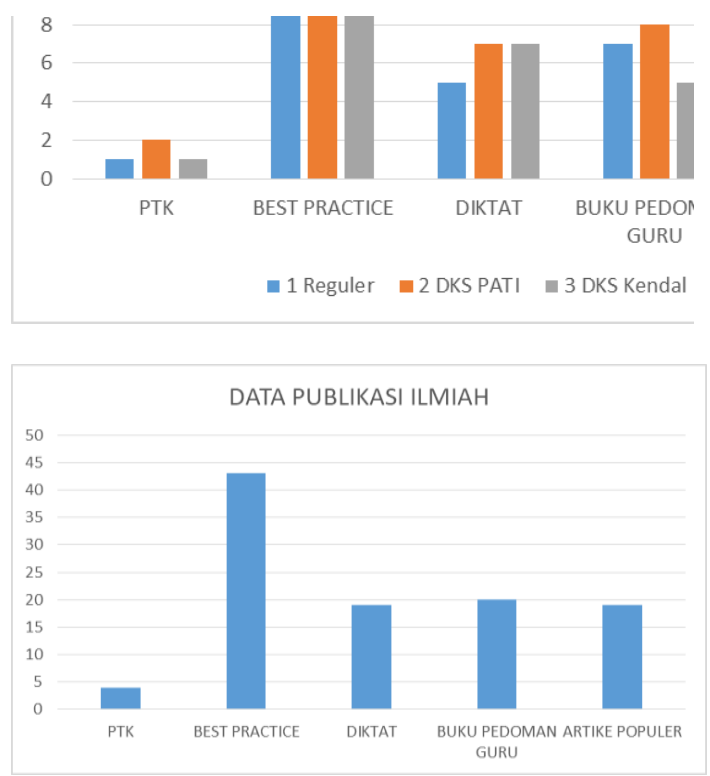

Grafik 2. Uji Luas hasil RTL

Hasil uji coba lebih luas, hasil penelitian 3,8\%, tinjauan ilmiah (best practice) $40,95 \%$, buku $37,14 \%$ dan artikel populer $18,09 \%$. Meskipun tinjauan ilmiah masih di bawah 50\%, namun masih mendominasi di antara publikasi yang lainnya.

Pengembangan model yang telah memperoleh validasi dari ahli materi dan ahli publikasi digunakan sebagai pembimbingan publikasi ilmiah. Dalam pembimbingan selama sebulan peserta diklat dapat melakukan konsultasi sesuai dengan program kurikulum yang telah dikembangkan khususnya untuk tinjaun ilmiah (best practice). Pembimbingan dilakukan sesuai dengan proporsi jumlah jam pelajaran (JP) yang dialokasikan dalam waktu 1 bulan.
Tabel 3. Komponen Jadwal Pelaksanaan Kurikulum Tinjauan Ilmiah

\begin{tabular}{|c|c|c|c|c|c|}
\hline NO & KOMPONEN & $\begin{array}{c}\mathbf{M} \\
\mathbf{1}\end{array}$ & $\begin{array}{l}\mathbf{M} \\
2 \\
\end{array}$ & $\begin{array}{l}\mathbf{M} \\
\mathbf{3}\end{array}$ & $\begin{array}{l}M \\
4 \\
\end{array}$ \\
\hline \multicolumn{6}{|c|}{ ISI MAKALAH } \\
\hline & judul & V & & & \\
\hline \multirow{5}{*}{$\begin{array}{l}\text { A. } \\
\text { B. }\end{array}$} & Pendahuluan & $\mathrm{V}$ & & & \\
\hline & $\begin{array}{l}\text { 1. Latar } \\
\text { Belakang }\end{array}$ & & & & \\
\hline & $\begin{array}{l}\text { 2. perumusan } \\
\text { masalah }\end{array}$ & & & & \\
\hline & 3. Tujuan & & & & \\
\hline & 4. Manfaat & & & & \\
\hline \multirow[t]{4}{*}{ C. } & $\begin{array}{l}\text { Kajian/tinjauan } \\
\text { pustaka }\end{array}$ & & V & & \\
\hline & Teori yang & & & & \\
\hline & $\begin{array}{l}\text { mendasari } \\
\text { permasalahan }\end{array}$ & & & & \\
\hline & yang diangkat & & & & \\
\hline \multirow[t]{7}{*}{ D. } & Pembahasan & & & $\mathrm{V}$ & \\
\hline & masalah & & & & \\
\hline & Kondisi awal & & & & \\
\hline & Proses & & & & \\
\hline & $\begin{array}{l}\text { penyelesaian } \\
\text { masalah }\end{array}$ & & & & \\
\hline & Kendala yang & & & V & \\
\hline & dihadapi & & & & \\
\hline \multirow[t]{2}{*}{ E. } & Kesimpulan & & & & \\
\hline & $\begin{array}{l}\text { Intisari dari best } \\
\text { practice }\end{array}$ & & & V & \\
\hline \multirow[t]{3}{*}{ F. } & Daftar pustaka & & & & \\
\hline & Kesesuaian & & & & \\
\hline & $\begin{array}{l}\text { sumber yang } \\
\text { dirujuk }\end{array}$ & & & & \\
\hline \multirow[t]{10}{*}{ G. } & Lampiran- & & & V & \\
\hline & Lampiran & & & & \\
\hline & c. data yang & & & & \\
\hline & $\begin{array}{l}\text { digunakan } \\
\text { dalam }\end{array}$ & & & & \\
\hline & melakukan & & & & \\
\hline & tinjauan & & & & \\
\hline & ilmiah & & & & \\
\hline & d. dokumen & & & & \\
\hline & $\begin{array}{l}\text { menuujang } \\
\text { tinjauan }\end{array}$ & & & & \\
\hline & ilmiah & & & & \\
\hline H. & Pengumpulan & & & & $\mathrm{V}$ \\
\hline & Makalah & & & & \\
\hline
\end{tabular}

Dari hasil data tersebut kurikulum publika ilmiah setiap mata diklat perlu dikembangkan sebagai pedoman implementasi tindak lanjut kediklatann publikasi ilmiah. Dalam penelitian ini yang dikembangkan mata diklat tinjainjauan ilmiah (best practice), dalam penentuan 
alokasi waktu setiap mata diklat 15 jam pelajaran. Setiap mata diklat dapat dijabarkan sesuai dengan sistematika penulisan karya ilmiah. Pembimbingan dapat dilakukan setiap minggu sesuai dengan proporsi penulisan.

\section{PENUTUP}

\section{Simpulan}

Hasil dari penelitian yang dilakukan merupakan pengembangan kurikulum dari Kurikulum Diklat Publikasi Ilmiah Kurikulum yang terdapat dalam SK Kepala Badan Litbang dan Diklat No 62 Tahun 2017 tentang Kurikulum Pendidikan dan Pelatihan Tenaga Teknis Pendidikan dan Keagamaan. Berdasarkan hasil penelitian pada pembahasan, menjelaskan bahwa :

1. Kurikulum diklat publikasi ilmiah yang dari tahapan uji coba $50 \%$ dan uji luas 40,95\%, tinjauan ilmiah (best practice) menjadi fokus penulisan publikasi ilmiah

2. Pengembangan model melalui validasi ahli materi $83,3 \%$ dan dari ahli publikasi $76 \%$

Dari hasil tersebut maka kurikulum publikasi ilmiah mata diklat tinjauan ilmiah dapat dikembangkan dan dapat dijadikan pedoman pembimbingan.

\section{Saran}

Saran yang dapat disampaikan berkaitan dengan penelitian ini perlu adanya perhatian, dukungan, dan komitmen bersama dari Kepala Balai Diklat Keagamaan Semarang dan jajarannya bersama widyaiswara untuk mendukung kegiatan perkonsultasian fasilitasi ini dengan sungguh-sungguh.

Perlu adanya dukungan dan komitmen dari seluruh pejabat yang akan menjadi stakeholders baik yang langsung maupun yang tidak langsung untuk dapat mengikuti proses perkonsultasian fasilitasi ini sesuai dengan jadwal yang telah ditetapkan.

\section{DAFTAR PUSTAKA}

Hamalik, O. (2014). Kurikulum dan Pembelajaran. Jakarta: PT Bumi Aksara. JakartaT : PT Bumi Aksara.

Idi, A. (2011). Pengembangan Kurikulum: Teori dan Praktik. Yogyakarta: Ar-Ruzz Media. Yogyakarta: Ar-Ruzz Media.

Kemenag. (2015). Peraturan Menteri Agama (PMA) No 75 tahun 2015 tentang Penyelengaraan Pendidikan dan Pelatihan Pegawai pada Kementerian Agama. Jakarta.

Kemendiknas. (2007). Peraturan Menteri Pendidikan Nasional Republik Indonesia Nomor 16 Tahun 2007 tetang Standar Kulifikasi Akademik dan Kompetensi Guru. Jakarta.

Nasional., K. P. (2010). Buku 4 Pembinaan dan Pengembangan Profesi Guru Pedoman Kegiatan Pengembangan Keprofesian Berkelanjutan (PKB) dan Angka Kreditnya. Jakarta: Kementeria Pendidikan dan Kebudayaan.

Nasution. (2009). Metode Research (Penelitian Ilmiah). Jakarta: Bumi Aksara.

PerKaLAN. (2011). Peraturan Kepala Lembaga Administrasi Negara Nomor 26 Tahun 2011 tentang Pedoman Umum Pembinaan Penyelenggaraan Pendidikan dan Pelatihan Teknis. Jakarta.

PerKaLAN. (2015). Peraturan Kepala Lembaga Administrasi Negara Nomor 26 Tahun 2015 tentang Pedoman Penilaian Angka Kredit Jabatan Fungsional Widyaiswara. Jakarta.

Sanjaya, W. (2008). Kurikulum dan Pembelajaran. Jakarta: Kencana. 
Sudjana, N. (2005). Pembinaan dan Pengembangan Kurikulum. Bandung: Publikasi, FIP IKIP Bandung.

Sugiyono. (2009). Metode Penelitian Kuantitatif, Kualitatif dan R\&D, Bandung : Alfabeta. Bandung: Alfabeta.

Sukmadinata, N. (2009). Metode Penelitian Pendidikan. Bandung: Remaja Rosdakarya.

Suparlan. (2011). Tanya Jawab Pengembangan Kurikulum dan Materi Pembelajaran. Jakarta: PT Bumi Aksara h 79.

Suryani, E. (2017). Best Practice Pembelajaran Inovasi melalui Model Project Based Learning, Yogyakarta, Deepublish. Yogyakarta: Deepublish.

Sukirman, D. Tanpa tahun. Landasan Pengembangan Kurikulum [online]. Tersedia: http://file.upi.edu/Direktori/Fip/Jur.Pend.Luarbiasa/196209061986011-Ahmad Mulyadiprana/Pdf/Landasan Kurikulum.pdf (diakses 16 Februari 2017)

Undang-undang RI Nomor 20 Tahun 2003 tentang Sistem Pendidikan Nasional Undang-undang RI Nomor 14 Tahun 2005 tentang Guru dan Dosen. 